\title{
Stosowanie skojarzenia beta-adrenolityku i inhibitora konwertazy angiotensyny w leczeniu chorób układu sercowo-naczyniowego - spojrzenie kardiologa
}

\author{
Filip M. Szymański \\ I Katedra i Klinika Kardiologii, Warszawski Uniwersytet Medyczny, Warszawa
}

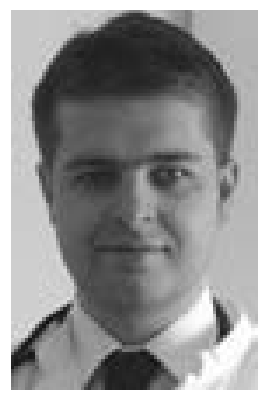

\section{WPROWADZENIE}

Skojarzenie $\beta$-adrenolityku i inhibitora konwertazy angiotensyny (ACEI) jest prawdopodobnie jednym z najczęściej wykorzystywanych połączeń w kardiologii. Dzieje się, tak ponieważ wskazania do stosowania obu grup leków są bardzo szerokie i często się pokrywają. Natomiast mechanizmy działania samych leków, ich działania dodatkowe oraz korzyści kliniczne wzajemnie się uzupełniają, co pozwala zredukować objawy i zwolnić progresję chorób sercowo-naczyniowych, a także poprawić rokowanie chorych [1-4]. Skuteczność $\beta$-adrenolityków i ACEl wielokrotnie potwierdzono w badaniach klinicznych obejmujących wiele grup pacjentów z chorobami układu sercowo-naczyniowego, co zaowocowało silnym ugruntowaniem pozycji obu grup leków w wytycznych Europejskiego Towarzystwa Kardiologicznego (ESC) oraz innych towarzystw naukowych. W niniejszym opracowaniu podjęto próbę określenia pozycji $\beta$-adrenolityków i ACEI w wytycznych ESC dotyczących chorób układu sercowo-naczyniowego na przykładzie bisoprololu i perindoprilu — jednych z molekuł tych grup o najlepiej udowodnionych korzyściach klinicznych. Nie ujęto jednak zaleceń dotyczących stosowania $\beta$-adrenolityków i ACEI w leczeniu nadciśnienia tętniczego, ponieważ zagadnienie to zostało dokładnie omówione w artykułach prof. dra hab. n. med. Andrzeja Januszewicza oraz dra hab. n. med. Aleksandra Prejbisza, które zostały opublikowane w niniejszym suplemencie do czasopisma „Kardiologia Polska”.

\section{MIEJSCE BETA-ADRENOLITYKÓW I ACEI W LECZENIU CHOROBY WIEŃCOWEJ}

W aktualnych wytycznych ESC dotyczących leczenia stabilnej choroby wieńcowej dość szczegółowo opisano miejsce $\beta$-adrenolityków I ACEI, przypisując im jednocześnie dwie odmienne funkcje $w$ leczeniu tego schorzenia [5]. Zapisy dotyczące ACEI oraz $\beta$-adrenolityków brzmią odpowiednio:

- "Inhibitory konwertazy angiotensyny zmniejszają umieralność ogólną i częstość występowania zawału serca, udarów mózgu oraz niewydolności serca w pewnych podgrupach pacjentów, w tym u osób z niewydolnością serca, uprzednio rozpoznaną chorobą układu naczyniowego lub cukrzycą z grupy dużego ryzyka. Dlatego też należy rozważyć podawanie inhibitorów konwertazy angiotensyny pacjentom ze stabilną chorobą wieńcową, zwłaszcza ze współistniejącym nadciśnieniem tętniczym, frakcją wyrzutową lewej komory $\leq 40 \%$, cukrzycą lub przewlekłą chorobą nerek, chyba że występują przeciwwskazania do stosowania tych leków." [5];

- "Beta-adrenolityki działają bezpośrednio na serce, zmniejszając częstotliwość rytmu serca, kurczliwość mięśnia sercowego, przewodzenie przedsionkowo-komorowe i aktywność ektopową. Mogą one również zwiększać perfuzję niedokrwionych obszarów poprzez wydłużanie rozkurczu i zwiększanie oporu naczyniowego w obszarach bez niedokrwienia. U pacjentów po zawale serca $\beta$-adrenolityki spowodowały redukcję ryzyka zgonów z przyczyn sercowo-naczyniowych i zawału serca o $30 \%$. Beta-adrenolityki są niewątpliwie skuteczne jako leki zmniejszające dławicę wywołaną wysiłkiem,

\section{Adres do korespondencji:}

dr hab. n. med. Filip M. Szymański, I Katedra i Klinika Kardiologii, Warszawski Uniwersytet Medyczny, ul. Banacha 1A, 02-097 Warszawa, tel: +48 22 599 19 58, faks: +48 2259919 57, e-mail: filip.szymanski@wum.edu.pl

Suplement: Copyright (c) „Via Medica sp. z o.o." sp.k. 2017 
Tabela 1. Podsumowanie zaleceń dotyczących stosowania inhibitorów konwertazy angiotensyny i $\beta$-adrenolityków w stabilnej chorobie wieńcowej [5]

\begin{tabular}{|l|c|c|}
\hline \multicolumn{2}{|l|}{ Zwalczanie dławicy piersiowej } & I A \\
\hline $\begin{array}{l}\text { W ramach terapii pierwszego rzutu zaleca się } \beta \text {-adrenolityki i/lub antagonistów wapnia w celu kontroli } \\
\text { czytmu serca i objawów klinicznych }\end{array}$ & & C Ila \\
\hline U bezobjawowych pacjentów z dużym obszarem niedokrwienia (> 10\%) należy rozważać $\beta$-adrenolityki & Ila & B \\
\hline $\begin{array}{l}\text { U pacjentów z dławicą naczynioskurczową należy rozważać antagonistów wapnia i azotany, } \\
\text { natomiast unikać stosowania } \beta \text {-adrenolityków }\end{array}$ & \\
\hline $\begin{array}{l}\text { Prewencja incydentów } \\
\text { Zaleca się stosowanie inhibitorów konwertazy angiotensyny (lub sartanów) w przypadku występowania innych } \\
\text { stanów (np. niewydolność serca, nadciśnienie tętnicze lub cukrzyca) }\end{array}$ & I & A \\
\hline
\end{tabular}

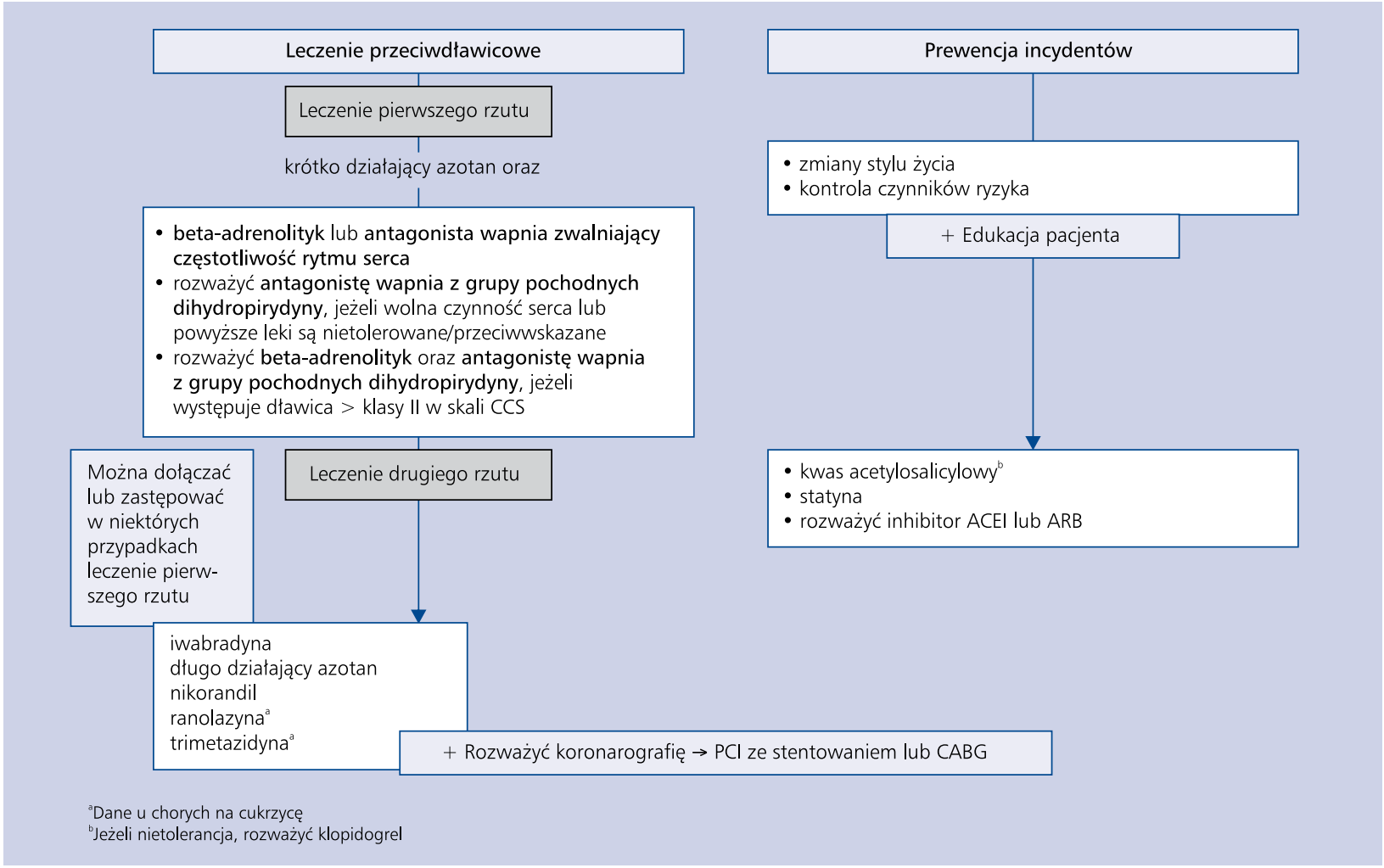

Rycina 1. Leczenie zachowawcze u pacjentów ze stabilną chorobą wieńcową; ACEI — inhibitor konwertazy angiotensyny; ARB — antagonista receptora angiotensynowego; CABG — pomostowanie tętnic wieńcowych; CCS — Kanadyjskie Towarzystwo Kardiologiczne; $\mathrm{PCl}$ — przezskórna interwencja wieńcowa; na podstawie [5]

zwiększające tolerancję wysiłku fizycznego oraz ograniczające zarówno objawowe, jak i bezobjawowe epizody niedokrwienia (...). Podsumowując, uzyskano dowody prognostycznych korzyści ze stosowania $\beta$-adrenolityków u pacjentów po zawale serca lub z niewydolnością serca. Na podstawie ekstrapolacji tych danych można sądzić, że $\beta$-adrenolityki mogą być lekami przeciwdławicowymi pierwszego rzutu u pacjentów ze stabilną chorobą wieńcową bez przeciwwskazań." [5].

Zalecenia dotyczące stosowania ACEI oraz $\beta$-adrenolityków w stabilnej chorobie wieńcowej podsumowano w tabeli 1. Powyższe wytyczne mają także swoje odzwierciedlenie w dobrze znanym Czytelnikom wykresie pozycjonującym poszczególne leki w terapii stabilnej choroby wieńcowej (ryc. 1).

\section{MIEJSCE BETA-ADRENOLITYKÓW I ACEI W LECZENIU NIEWYDOLNOŚCI SERCA}

Najnowsze, opublikowane w 2016 roku, wytyczne ESC dotyczące ostrej i przewlekłej niewydolności serca, w leczeniu długoterminowym pozycjonują ACEI i $\beta$-adrenolityki w sposób następujący: 
Tabela 2. Podsumowanie zaleceń dotyczących stosowania inhibitorów konwertazy angiotensyny i $\beta$-adrenolityków w przewlekłej niewydolności serca [6]

\begin{tabular}{|l|c|c|}
\hline \multicolumn{1}{|c|}{ Zalecenie } & Klasa & Poziom \\
\hline $\begin{array}{l}\text { Zaleca się stosowanie inhibitorów konwertazy angiotensyny w połączeniu z } \beta \text {-adrenolitykiem u pacjentów } \\
\text { z objawową niewydolnością serca ze zmniejszoną frakcją wyrzutową lewej komory w celu redukcji ryzyka } \\
\text { hospitalizacji z powodu niewydolności serca i zgonu }\end{array}$ & I & A \\
\hline $\begin{array}{l}\text { Zaleca się stosowanie } \beta \text {-adrneolityku w połączeniu z inhibitorem konwertazy angiotensyny u pacjentów } \\
\text { ze stabilną, objawową niewydolnością serca ze zmniejszoną frakcją wyrzutową lewej komory w celu redukcji } \\
\text { ryzyka hospitalizacji z powodu niewydolności serca i zgonu }\end{array}$ & I & A \\
\hline
\end{tabular}

- „Dla inhibitorów konwertazy angiotensyny udowodniono redukcję śmiertelności i zachorowalności u pacjentów z niewydolnością serca z obniżoną frakcją wyrzutową lewej komory i są rekomendowane w przypadku braku przeciwwskazań lub nietolerancji u wszystkich pacjentów z objawami. Inhibitory konwertazy angiotensyny powinny być stosowane w maksymalnej tolerowanej dawce, aby zapewnić odpowiednią blokadę układu renina-angiotensyna-aldosteron (...). Inhibitory konwertazy angiotensyny są również zalecane u pacjentów z bezobjawową dysfunkcją skurczową lewej komory w celu redukcji ryzyka rozwoju niewydolności serca, hospitalizacji z powodu niewydolności serca i zgonu." [6];

- „Beta-adrenolityki redukują śmiertelność i zachorowalność u pacjentów z objawową niewydolnością serca z obniżoną frakcją wyrzutową lewej komory pomimo leczenia inhibitorem konwertazy angiotensyny i w większości przypadków diuretykiem (...). Uznaje się, że leczenie $\beta$-adrenolitykiem i inhibitorem konwertazy angiotensyny uzupełnia się wzajemnie i powinno być rozpoczynane równocześnie, najwcześniej jak tylko postawiona została diagnoza (...). Beta-adrenolityki zalecane są także u pacjentów z wywiadem zawału serca lub bezobjawową dysfunkcją lewej komory." [6].

Ponownie, jak w przypadku wytycznych dotyczących stabilnej choroby wieńcowej, zalecenia odnoszące się do stosowania omawianych leków podsumowano w tabeli 2 i na rycinie 2.

\section{MIEJSCE BETA-ADRENOLITYKÓW I ACEI}

\section{W LECZENIU MIGOTANIA PRZEDSIONKÓW}

Również w tegorocznych wytycznych dotyczących migotania przedsionków, arytmii najczęściej występującej w populacji, przedstawiono miejsce ACEl i $\beta$-adrenolityków w terapii tego schorzenia. Chociaż ACEI nie poświęcono osobnego rozdziału, to w wielu miejscach dotyczących zapobiegania wystąpieniu arytmii, np. u osób z niewydolnością serca czy nadciśnieniem tętniczym, dodano zalecenia na temat ich stosowania. Wytyczne te podsumowano w tabeli 3 [7].
Natomiast $\beta$-adrenolityki traktowane są jako leki wpływające na rytm serca i w odniesieniu do nich w wytycznych znajduje się następująca informacja: "Monoterapia $\beta$-adrenolitykiem jest często pierwszą linią leczenia w celu kontroli częstości rytmu serca (...). Autorzy wytycznych uznają $\beta$-adrenolityki za użyteczny sposób leczenia pierwszego wyboru w celu kontroli częstości rytmu serca u wszystkich pacjentów z migotaniem przedsionków, aby zmniejszyć objawy i poprawić funkcjonowanie, przy braku niekorzystnych działań i dobrej tolerancji u pacjentów w każdym wieku." [7].

\section{DLACZEGO SPOŚRÓD DOSTĘPNYCH MOLEKUŁ WARTO WYBIERAĆ PREPARAT ZŁOŻONY ZAWIERAJĄCY PERINDOPRIL I BISOPROLOL?}

Omawiając zagadnienie dotyczące połączenia perindoprilu i bisoprololu, należy krótko wspomnieć o skuteczności tych molekuł przyjmowanych osobno, a następnie zwrócić uwagę na korzyści kliniczne, jakie mogą odnieść pacjenci, którzy obie molekuły stosują równocześnie.

Badania pokazują, że u pacjentów z chorobami układu sercowo-naczyniowego ACEI powodują redukcję incydentów sercowo-naczyniowych, udaru mózgu, zawału serca, zgonów sercowo-naczyniowych i nowych przypadków niewydolności serca [3]. W wielu randomizowanych badaniach kontrolnych analizowano skuteczność perindoprilu w różnych grupach chorych. Randomizowanym, podwójnie zaślepionym badaniem EUROPA objęto 12218 pacjentów ze stabilną chorobą wieńcową, bez niewydolności serca, których losowo włączono do grupy przyjmującej perindopril w dawce $8 \mathrm{mg}$ na dobę lub do grupy otrzymującej placebo. Chorych poddano obserwacji trwającej 4,2 roku. Zaobserwowano redukcję ryzyka o 20\% w przypadku pierwotnego, złożonego punktu końcowego (zgonu sercowo-naczyniowego, zawału serca lub zreanimowanego zatrzymania krążenia) w grupie osób przyjmujących perindopril vs. placebo. Korzyści były widoczne we wszystkich wstępnie zdefiniowanych grupach i były niezależne od zastosowanej wcześniej terapii standardowej, włączając w to leki przeciwpłytkowe, hipolipemizujące i $\beta$-adrenolityki [8].

W 12-miesięcznej randomizowanej, podwójnie zaślepionej próbie PREAMI przebadano 1252 pacjentów w wieku 


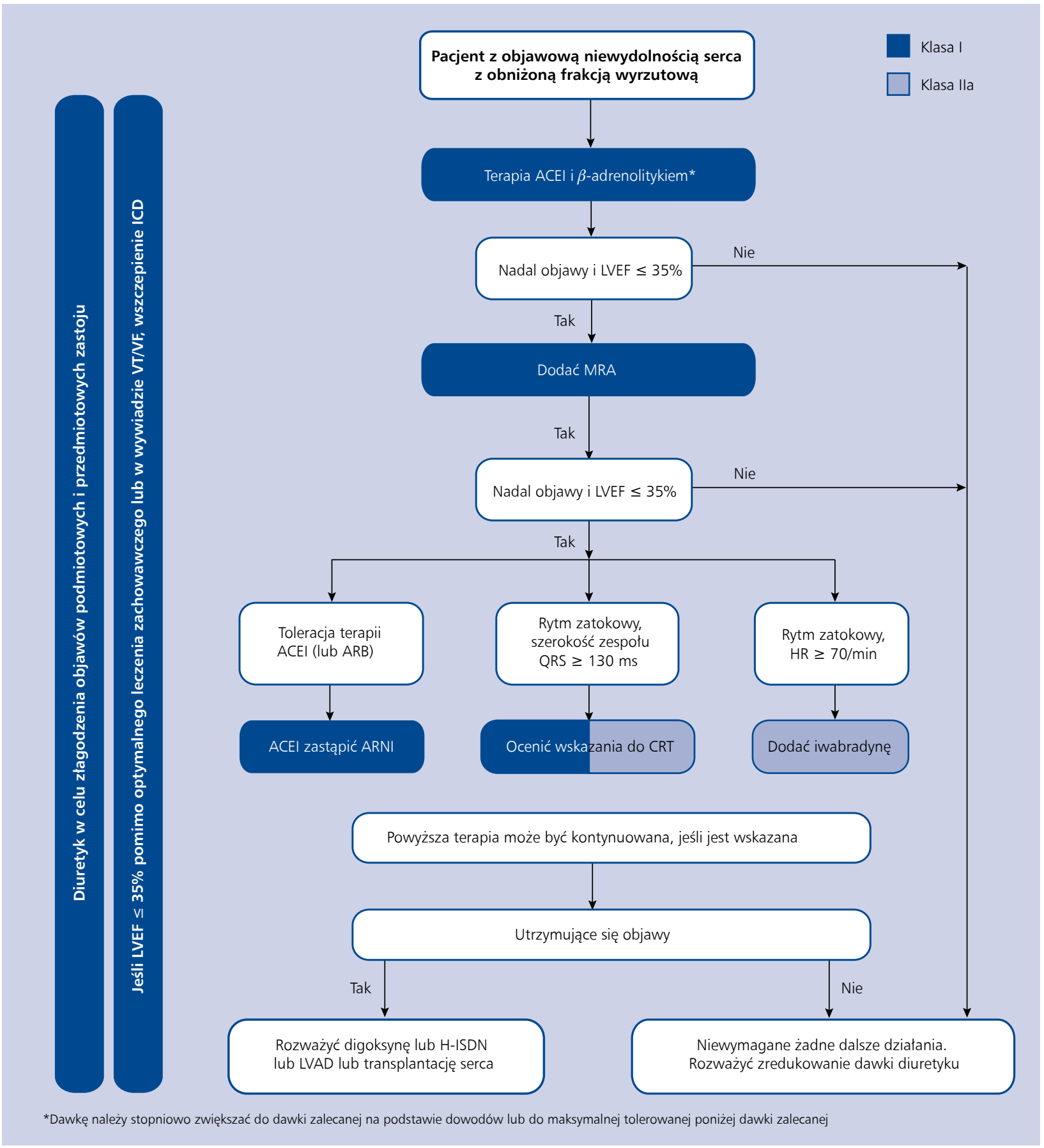

Rycina 2. Zalecenia dotyczące farmakoterapii przewlekłej niewydolności serca ze zmniejszoną frakcją wyrzutową lewej komory; ACEI - inhibitor konwertazy angiotensyny; ARB - antagonista receptora dla angiotensyny; ARNI — antagonista receptora dla angiotensyny i inhibitor neprilizyny; CRT — terapia resynchronizująca serca; H-ISDN — połączenia hydralazyny i dwuazotanu izosorbidu; HR — częstość rytmu serca; ICD — wszczepialny kardiowerter-defibrylator; LVAD — urządzenie wspomagające pracę lewej komory; LVEF — frakcja wyrzutowa lewej komory; MRA — antagonista receptora mineralokortykoidowego/aldosteronowego; VF — migotanie komór; VT — częstoskurcz komorowy; na podstawie [6]

podeszłym, z przebytym niedawno zawałem serca, ale z zachowaną frakcją wyrzutową lewej komory. Chorym zalecono stosowanie perindoprilu w dawce $8 \mathrm{mg}$ na dobę lub placebo. Zaobserwowano, że stosowanie perindoprilu wiązało się z istotnym (o 38\%) zmniejszeniem $(p<0,001)$ w zakresie pierwotnego punktu końcowego (zgonu, hospitalizacji z powodu niewydolności serca i remodelingu mięśnia sercowego). Zanotowano również, że u pacjentów przyjmujących perin- 
Tabela 3. Podsumowanie zaleceń dotyczących stosowania inhibitorów konwertazy angiotensyny i $\beta$-adrenolityków w migotaniu przedsionków [7]

\begin{tabular}{|l|c|c|}
\hline \multicolumn{1}{|c|}{ Zalecenie } & Klasa & Poziom \\
\hline $\begin{array}{l}\text { Beta-adenolityki, digokysna, diltiazem lub werapamil są rekomendowane w celu kontroli częstotliwości rytmu } \\
\text { serca u pacjentów z migotaniem przedsionków i frakcją wyrzutową lewej komory } \geq 40 \%\end{array}$ & I & B \\
\hline $\begin{array}{l}\text { Beta-adenolityki i/lub digokysna są rekomendowane w celu kontroli częstotliwości rytmu serca u pacjentów } \\
\text { z migotaniem przedsionków i frakcją wyrzutową lewej komory < 40\% }\end{array}$ & I & B \\
\hline $\begin{array}{l}\text { Inhibitory konwertazy angiotensyny, sartany i } \beta \text {-adrenolityki powinny być rozważone w ramach prewencji } \\
\text { wystąpienia migotania przedsionków u pacjentów z niewydolnością serca ze zmniejszoną frakcją wyrzutową }\end{array}$ & Ila & A \\
\hline $\begin{array}{l}\text { Inhibiotry konwertazy angiotensyny i sartany powinny być rozważone w ramach prewencji wystąpienia } \\
\text { migotania przedsionków u pacjentów z nadciśnieniem tętniczym, zwłaszcza z przerostem lewej komory }\end{array}$ & Ila & B \\
\hline $\begin{array}{l}\text { Wstępne leczenie inhibitorami konwertazy angiotensyny i sartanami może być rozważone u pacjentów } \\
\text { z nawracającym migotaniem przedsionków poddawanych kardiowersji elektrycznej lub przyjmujących } \\
\text { leki antyarytmiczne }\end{array}$ & Illb & B \\
\hline $\begin{array}{l}\text { Inhibiotry konwertazy angiotensyny i sartany nie są wskazane w prewencji wtórnej napadowego migotania } \\
\text { przedsionków u pacjentów z niewielką lub bez wspótistniejącej choroby serca }\end{array}$ & III & B \\
\hline
\end{tabular}

Tabela 4. Miejsce bisoprololu wśród stosowanych obecnie $\beta$-adrenolityków

\begin{tabular}{|c|c|c|c|}
\hline Generacja & Grupy & Charakterystyka & Przykłady \\
\hline \multirow[t]{2}{*}{ I generacja } & IA & Niekardioselektywne, z wewnętrzną aktywnością sympatykomimetyczną & $\begin{array}{c}\text { oksprenolol } \\
\text { pindolol }\end{array}$ \\
\hline & IB & Niekardioselektywne, bez wewnętrznej aktywności sympatykomimetycznej & $\begin{array}{c}\text { propanolol } \\
\text { nadolol }\end{array}$ \\
\hline \multirow[t]{3}{*}{ II generacja } & $\| \mathrm{A}$ & Kardioselektywne, z wewnętrzną aktywnością & $\begin{array}{l}\text { acebutolol } \\
\text { celiprolol }\end{array}$ \\
\hline & $\| B$ & Kardioselektywne, bez wewnętrznej aktywności & $\begin{array}{c}\text { anenolol } \\
\text { metoprolol }\end{array}$ \\
\hline & $\| C$ & Bez wewnętrznej aktywności, o znacząco podwyższonej kardioselektywności & $\begin{array}{l}\text { betaksolol } \\
\text { bisoprolol }\end{array}$ \\
\hline III generacja & III & Dodatkowe właściwości plejotropowe i działanie wazodylatacyjne & $\begin{array}{l}\text { karwedilol } \\
\text { nebiwolol }\end{array}$ \\
\hline
\end{tabular}

dopril remodeling serca występował znacznie rzadziej niż u osób przyjmujących placebo (27,7\% vs. 51,2\%, względna redukcja ryzyka [RRR] 46\%; $p<0,001)[9,10]$.

W randomizowanym, podwójnie zaślepionym badaniu PROGRESS u 6105 pacjentów z wywiadem udaru mózgu lub przejściowego ataku niedokrwiennego wykazano, że stosowanie perindoprilu \pm indapamidu wiązało się z redukcją ryzyka ponownego incydentu mózgowego (10\% vs. 14\%) w porównaniu z placebo (RRR 28\%; p < 0,0001) w czasie obserwacji wynoszącej średnio 3,9 roku. Połączenie zawierające perindopril powodowało także zmniejszenie ryzyka zawału serca niezakończonego zgonem - o 38\% oraz zastoinowej niewydolności serca - o 26\% ( $p=0,02)[11,12]$.

Natomiast bisoprolol to wysoce selektywny antagonista receptora $\beta 1$-adrenergicznego, który jest pozbawiony aktywności sympatykomimetycznej oraz nie wykazuje właściwości stabilizujących błonę komórkową. Według stosowanego obecnie podziału $\beta$-adrenolityków zalicza się go do grupy II C (tab. 4).
W odniesieniu do bisoprololu najważniejszą serię prób stanowią analizy badania CIBIS dotyczące pacjentów z niewydolnością serca, a więc patologii często obserwowanej u osób z zaawansowaną chorobą wieńcową $[2,13]$. Pacjentów z niewydolnością serca (III lub IV klasa wg NYHA) losowo włączano do grupy przyjmującej bisoprolol (we wstępnej dawce 1,25 mg zwiększanej do maksimum 5 mg [CIBIS] lub 10 mg [CIBIS II]) bądź placebo. Chorzy byli poddani także standardowej terapii niewydolności serca (ACEI i diuretyk). Śmiertelność całkowita była istotnie niższa u pacjentów otrzymujących bisoprolol w porównaniu z placebo w badaniu CIBIS II (11,8\% vs. $17,3 \%$ ), niezależnie od zastosowanej dawki. W badaniu CIBIS II odnotowano istotną redukcję występowania zgonów sercowo-naczyniowych (9\% vs. 12\%) i hospitalizacji (33\% vs. 39\%) w grupie otrzymującej bisoprolol w porównaniu z grupą przyjmującą placebo. W metaanalizie badań CIBIS i CIBIS II ( $\mathrm{n}=3288$ ) wykazano 29-procentowe zmniejszenie całkowitego ryzyka zgonu u osób stosujących bisoprolol vs. placebo. 


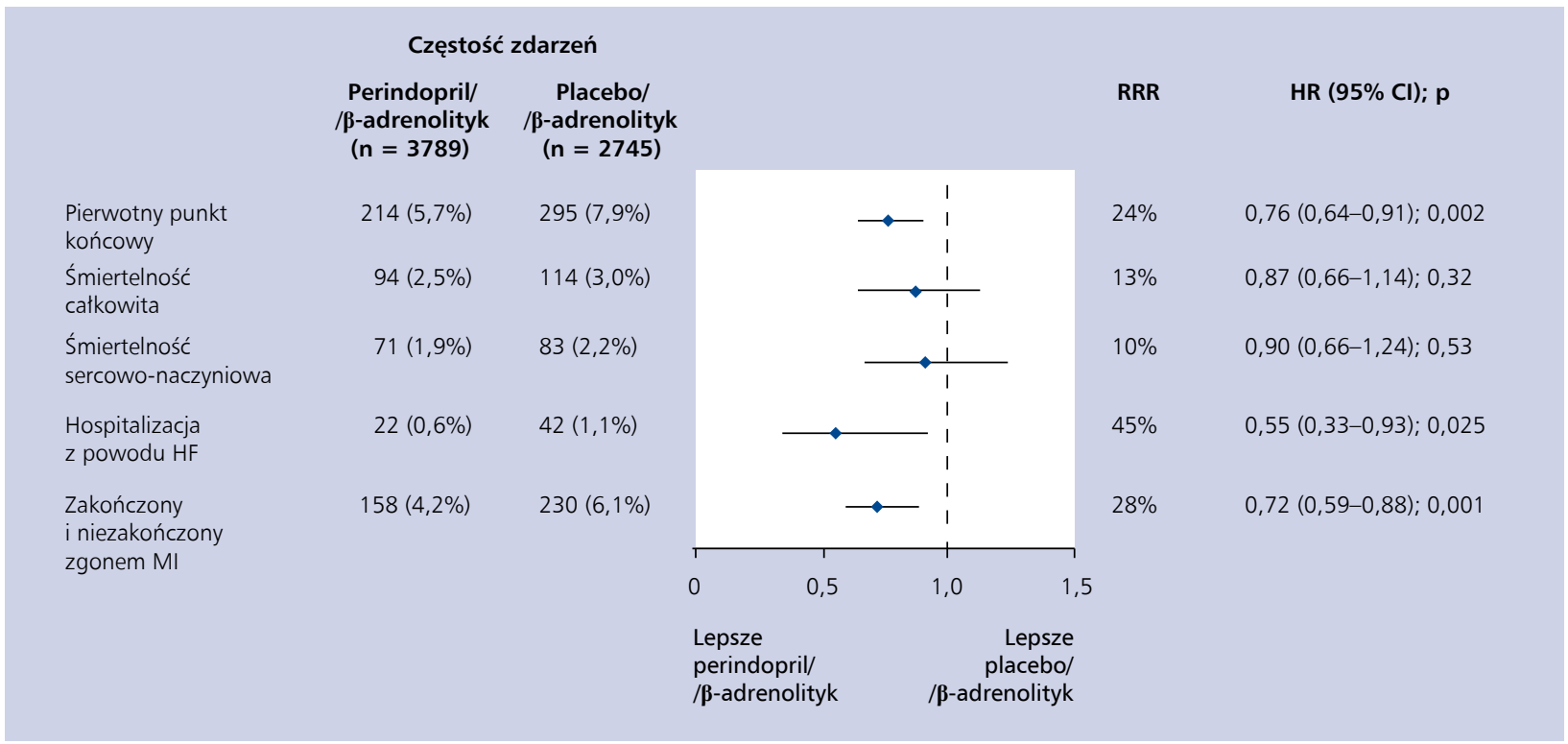

Rycina 3. Redukcja ryzyka sercowo-naczyniowego u pacjentów ze stabilną chorobą wieńcową przyjmujących $\beta$-adrenolityki, u których do terapii włączono perindopril; $\mathrm{Cl}$ — przedział ufności; HR — ryzyko względne; HF — niewydolność serca; $\mathrm{Ml}$ — zawał serca; RRR — względna redukcja ryzyka; na podstawie [4]

Bisoprolol powodował redukcję ryzyka zgonu u pacjentów z niewydolnością serca niezależnie od jej etiologii i nasilenia.

Skuteczność połączenia $\beta$-adrenolityku z ACEI również doczekało się potwierdzenia w badaniach klinicznych. Bardzo interesujące i przekonujące dane pochodzą z opublikowanej niedawno analizy Bertranda i wsp. [4], która dotyczyła grupy pacjentów objętych badaniem EUROPA, a więc osób ze stabilną chorobą wieńcową. Do omawianej analizy włączono wyłącznie pacjentów przyjmujących wyjściowo $\beta$-adrenolityk (7534 osób). Następnie, zgodnie z protokołem badania, zostali oni zrandomizowani do grupy stosującej perindopril lub do grupy otrzymującej placebo oraz poddani obserwacji trwającej 4,2 roku. Pacjentów obserwowano pod kątem wystąpienia incydentów sercowo-naczyniowych i zgonu z przyczyn ogólnych lub z powodu chorób sercowo-naczyniowych. Wykazano, że leczenie połączeniem perindoprilu z $\beta$-adrenolitykiem zmniejszało względne ryzyko wystąpienia pierwotnego, złożonego punktu końcowego (zgon z przyczyn sercowo-naczyniowych, zawał serca i zresuscytowane zatrzymanie krążenia) o $24 \%$ w porównaniu z połączeniem placebo z $\beta$-adrenolitykiem (ryzyko względne [HR] 0,76; 95-procentowy przedział ufności [95\% Cl] 0,64-0,91; $p=0,002$ ). Dodanie do terapii perindoprilu zmniejszało także ryzyko zawału serca - o 28\% (HR 0,72; 95\% Cl 0,59-0,88; p =0,001) i hospitalizacji z powodu niewydolności serca - o 45\% (HR 0,55; 95\% Cl 0,33-0,93; p =0,025). Wyniki powyższej analizy ryzyka przedstawiono na rycinie 3 .

Przeprowadzono również badania kliniczne poświęcone konkretnie połączeniu perindoprilu z bisoprololem [14]. Omówione poniżej badanie miało na celu ustalenie, czy zastosowanie perindoprilu i bisoprololu wiąże się z redukcją procesu zapalnego. Takie działanie leków jest szczególnie istotne, ponieważ reakcja zapalna stanowi czynnik ryzyka sercowo-naczyniowego i element uczestniczący w patogenezie wielu chorób, z miażdżycą na czele. Im bardziej zaawansowana jest reakcja zapalna, tym szybsza jest progresja miażdżycy. Dlatego też działanie przeciwzapalne jest bardzo korzystne w prewencji chorób układu sercowo-naczyniowego. Do omawianego badania włączono pacjentów z nadciśnieniem tętniczym (których podzielono na dwie grupy: stopień 1., stopień 2.). W momencie włączenia do badania u pacjentów przeprowadzano 24-godzinne monitorowanie ciśnienia tętniczego (ABPM) oraz pomiary stężeń interleukin (IL): IL-1b, IL-6, IL-10 oraz czynnik chemotaktyczny monocytów i czynnik martwicy nowotworu alfa. Pacjentom z nadciśnieniem tętniczym 2. stopnia zalecono stosowanie połączenia bisoprololu (5 mg na dobę) i perindoprilu (4 mg na dobę), natomiast pacjentów z nadciśnieniem tętniczym 1. stopnia randomizowano do grupy przyjmującej bisoprolol w dawce $5 \mathrm{mg}$ na dobę lub perindopril w dawce $4 \mathrm{mg}$ na dobę. Następnie pacjentów poddano miesięcznej obserwacji i powtórzono oznaczenia markerów zapalnych oraz ABPM.

Można zauważyć, że zastosowanie obu molekuł w monoterapii wiązało się z istotną redukcją wartości ciśnienia tętniczego, która utrzymywała się w ciągu całej doby monitorowania, a to dodatkowo podkreśla długotrwały profil działania obu molekuł. W odniesieniu do parametrów reakcji zapalnej zaobserwowano istotny wpływ obu molekuł na stężenia cytokin. W porównaniu z pacjentami bez nadciśnienia tętniczego, stężenie IL-6 było o 69\% wyższe u chorych 
z łagodnym nadciśnieniem tętniczym oraz o 103\% wyższe u osób z umiarkowaną postacią choroby. Zastosowanie zarówno bisoprololu, jak i perindoprilu spowodowało istotny spadek stężenia tej cytokiny. Wskazuje to na prawdopodobny mechanizm, w którym - poza redukcją wartości ciśnienia tętniczego - połączenie bisoprololu i perindoprilu może się przyczyniać do zmniejszenia ryzyka sercowo-naczyniowego i poprawy rokowania pacjentów.

\section{PODSUMOWANIE}

Leki $\beta$-adrenolityczne i ACEI są bardzo chętnie i często stosowane równocześnie u pacjentów z chorobami układu sercowo-naczyniowego, takimi jak choroba niedokrwienna serca, niewydolność serca czy migotanie przedsionków. Przytoczone zapisy z wytycznych wskazują na komplementarność działania ACEI i $\beta$-adrenolityków we wszystkich wymienionych sytuacjach klinicznych. Tym bardziej zachęca to do ich łącznego stosowania, m.in. ze względu na to, że obydwie składowe charakteryzują się nie tylko udokumentowanym wpływem na poprawę rokowania, ale - co równie ważne — w przypadku leków złożonych długim czasem działania, co pozwala dawkować je raz na dobę. Z uwagi na zróżnicowaną skuteczność poszczególnych molekuł w obrębie klasy, wykorzystując w terapii wspomniane powyżej połączenie, warto skłaniać się w kierunku substancji o udowodnionej skuteczności, jakimi są np. bisoprolol i perindopril.

Za przyjmowaniem leku złożonego przemawiają również dodatkowe korzyści kliniczne, takie jak np. poprawa wskaźnika compliance. Długoterminowe przestrzeganie zaleceń lekarskich i wytrwałe stosowanie terapii nadal pozostaje istotnym problemem klinicznym. Nabiera to szczególnego znaczenia u pacjentów leczonych z przyczyn kardiologicznych, ze względu na kardioprotekcyjne działanie zarówno $\beta$-adrenolityków, jak i ACEI. Warto w tym miejscu przytoczyć wnioski z retrospektywnej obserwacji dotyczącej ponad 15 tysięcy pacjentów z chorobą wieńcową. Wykazano, że brak przestrzegania zaleceń w przypadku stosowania $\beta$-adrenolityków i ACEI wiązał się ze znaczącym wzrostem ryzyka zgonu. Wskaźnik nieprzestrzegania zasad stosowania poszczególnych grup leków wynosił, odpowiednio, 28,8\% i 21,6\%. W grupie nieprzestrzegającej zaleceń dotyczących przyjmowania $\beta$-adrenolityków zaobserwowano wzrost ryzyka zgonu o 50\% w porównaniu z grupą pacjentów, którzy ściśle przestrzegali wskazówek lekarza. W przypadku ACEI ryzyko zgonu rosło aż o 74\% [15].

Dotychczas leki złożone były dedykowane w większości pacjentom z nadciśnieniem tętniczym. Połączenie bisoprololu i perindoprilu, ze względu na swój skład, po raz pierwszy może być przeznaczone dla większej grupy osób ze schorzeniami kardiologicznymi, takimi jak choroba wieńcowa, niewydolność serca czy migotanie przedsionków. Uproszczenie schematu terapeutycznego, dzięki zastosowaniu leku złożonego, pozwoli na poprawę przestrzegania zaleceń przez pacjentów i - co się z tym wiąże - polepszenie skuteczności leczenia.

\section{Konflikt interesów: nie zgłoszono}

\section{Piśmiennictwo}

1. Fox KM; EURopean trial On reduction of cardiac events with Perindopril in stable coronary Artery disease Investigators. Efficacy of perindopril in reduction of cardiovascular events among patients with stable coronary artery disease: randomised, double-blind, placebo-controlled, multicentre trial (the EUROPA study). Lancet, 2003; 362: 782-768.

2. Lechat P, Escolano S, Golmard JL et al. Prognostic value of bisoprolol-induced hemodynamic effects in heart failure during the Cardiac Insufficiency BIsoprolol Study (CIBIS). Circulation, 1997; 96: 2197-205.

3. Savarese G, Costanzo P, Cleland JG et al. A meta-analysis reporting effects of angiotensin-converting enzyme inhibitors and angiotensin receptor blockers in patients without heart failure. J Am Coll Cardiol, 2013;61: 131-142. doi: 10.1016/j.jacc.2012.10.011.

4. Bertrand ME, Ferrari R, Remme WJ et al. Perindopril and beta-blocker for the prevention of cardiac events and mortality in stable coronary artery disease patients: a EUropean trial on Reduction Of cardiac events with Perindopril in stable coronary Artery disease (EUROPA) subanalysis. Am Heart J, 2015; 170: 1092-1098. doi: 10.1016/j.ahj.2015.08.018.

5. Montalescot G, Sechtem U, Achenbach S et al. 2013 ESC guidelines on the management of stable coronary artery disease: the Task Force on the management of stable coronary artery disease of the European Society of Cardiology. Eur Heart J, 2013; 34: 2949-3003.

6. Ponikowski P, Voors AA, Anker SD et al. 2016 ESC Guidelines for the diagnosis and treatment of acute and chronic heart failure: The Task Force for the diagnosis and treatment of acute and chronic heart failure of the European Society of Cardiology (ESC) Developed with the special contribution of the Heart Failure Association (HFA) of the ESC. Eur Heart J, 2016; 37: 2129-2200. doi: 10.1093/eurheartj/ehw128.

7. Kirchhof P, Benussi S, Kotecha D et al. 2016 ESC Guidelines for the management of atrial fibrillation developed in collaboration with EACTS: the Task Force for the management of atrial fibrillation of the European Society of Cardiology (ESC). Developed with the special contribution of the European Heart Rhythm Association (EHRA) of the ESC endorsed by the European Stroke Organisation (ESO). Eur Heart J, 2016 Aug 27. pii: ehw210. [Epub ahead of print]. doi: 10.1093/eurheartj/ehw210.

8. Fox KM. Efficacy of perindopril in reduction of cardiovascular events among patients with stable coronary artery disease: randomised, double-blind, placebo-controlled, multicentre trial (the EUROPA study). Lancet, 2003; 362: 782-788.

9. Nicolosi GL, Golcea $S$, Ceconi $C$ et al.; PREAMI Investigators. Effects of perindopril on cardiac remodelling and prognostic value of pre-discharge quantitative echocardiographic parameters in elderly patients after acute myocardial infarction: the PREAMI echo sub-study. Eur Heart J, 2009; 30: 1656-1665. doi: 10.1093/eurheartj/ehp139.

10. Ferrari R; Perindopril and Remodeling in Elderly with Acute Myocardial Infarction Investigators. Effects of angiotensin-converting enzyme inhibition with perindopril on left ventricular remodeling and clinical outcome: results of the randomized Perindopril and Remodeling in Elderly with Acute Myocardial Infarction (PREAMI) study. Arch Intern Med, 2006; 166: 659-666.

11. PROGRESS Collaborative Group. Effects of a perindopril based blood pressure lowering regimen on cardiac outcomes among patients with cerebrovascular disease. Eur Heart J, 2003; 24: $475-484$. 
12. PROGRESS Collaborative Group. Randomised trial of a perindopril-based blood-pressure-lowering regimen among 6,105 individuals with previous stroke or transient ischaemic attack. Lancet, 2001; 358: 1033-1041.

13. CIBIS-II Investigators and Committees. The Cardiac Insufficiency Bisoprolol Study II (CIBIS-II): a randomised trial. Lancet, 1999; 353: 9-13.
14. Madej A, Buldak L, Basiak M et al. The effects of 1 month antihypertensive treatment with perindopril, bisoprolol or both on the ex vivo ability of monocytes to secrete inflammatory cytokines. Int J Clin Pharmacol Ther, 2009; 47: 686-694.

15. Ho PM, Magid DJ, Shetterly SM et al. Rumsfeld JS. Medication nonadherence is associated with a broad range of adverseoutcomes in patients with coronary artery disease. 